\title{
Studi Pengembangan Air Terjun Tibu Sampi Sebagai Daya Tarik Wisata Di Kabupaten Tabanan
}

Gek Ayu Tahta Kurnia Natha Dewi a,1, I Nyoman Sunarta a, 2

1 tahtand@gmail.com, 2 nyoman_sunarta@unud.ac.id

a Program Studi S1 Destinasi Pariwisata, Fakultas Pariwisata,Universitas Udayana, Jl. Dr. R. Goris, Denpasar, Bali 80232 Indonesia

\section{Abstract}

Tibu sampi waterfall is a waterfall that has the potentiality and opportunities to be developed into a tourist attraction. However, the development of this waterfall has not been optimally reached. This study aims to determine the development of Tibu Sampi Waterfall as a tourist attraction.

This study uses qualitative data with data sources in the form of primary data and secondary data. Data sources are obtained through observation, interview and documentation techniques with the technique of determining individual sample selection.

The results of this study indicate that there are internal and external obstacles in the development of Tibu Waterfall as a tourist attraction. The internal obstacles are divided into three, namely the limited capital owned by Gunung Salak village; lack of adequate human resources in the field of tourism; and lack of promotion in the development of tourist attractions. The external obstacle is lack of contributions from investors.

of the various obstacles faced and slowing down the development of Tibu Waterfall as a tourist attraction, the community must create several efforts including the government or related parties to provide tourism education and training to the local community; to improve tourism products; to disseminate information in the form of brochures and guidebooks; to improve structuring and infrastructure; to cooperate with investors; to make local culture an attraction for tourists; and to develope tour packages.

Keywords: Study of development, tourist attraction, Gunung Salak Village, Tibu Sampi Waterfall

\section{PENDAHULUAN}

Pariwisata dianggap sebagai salah satu sektor yang memiliki dampak positif dalam hal peningkatan kondisi ekonomi, kondisi politik, dan kondisi sosial budaya. Dalam hal ekonomi pariwisata mampu memberikan banyak lapangan pekerjaan sehingga meningkatkan taraf hidup masyarakat di sekitar kawasan pariwisata. Pariwisata juga mampu merevitalisasi budaya-budaya yang tela lama ditinggalkan sehingga berkembang kembali dan menjadi suatu produk wisata unggulan. Kini dalam pengembangan pariwasata, pemerintah daerah diberi kewenangan dalam mengatur dan mengelola seluruh potensi-potensi wisata yang ada di daerahnya.

Pesatnya perkembangan pariwiasata di Bali membuat banyak memunculkan atraksi-atraksi wisata baru di setiap daerah yang memiliki potensi. Atraksi wisata yang dikembangkan berupa atraksi wisata yang menyuguhkan pemandangan alam, daya tarik wisata buatan hingga yang menampilkan adat istiadat, budaya dan kesenian lokal.

Bali memiliki 9 Kabupaten yang salah satu diantaranya adalah Kabupaten Tabanan. Secara geografis kabupaten
Tabanan terletak pada posisi yang cukup strategis karena berbatasan dengan Kabupaten Badung di sebelah Timur, sedangkan di Utara berbatasan dengan Kabupaten Buleleng, di sebelah Barat berbatasan dengan Kabupaten Jembrana dan sebelah Selatan berbatasan dengan Samudra Indonesia. Kabupaten Tabanan memiliki banyak daya tarik wisata yang menarik, selain Bedugul, Tanah Lot dan Jatiluwih, masih banyak daya tarik wisata yang belum berkembang dan belum banyak diketahui wisatawan.

Salah satu desa di Kabupaten Tabanan yang memiliki banyak daya tarik wisata yang belum terkenal yaitu di Desa Gunung Salak. Secara tofografi Desa Gunung Salak terletak di Kecamatan Selemadeg Timur, Kabupaten Tabanan yang merupakan daerah berbukit dengan ketinggian \pm 300400 meter diatas permukaan laut, curah hujan relatif sedang, dengan batas wilayah administratif sebagai berikut : Sebelah Utara berbatasan dengan Desa Dalang, Sebelah Timur berbatasan dengan Tukad Yeh Lambuk, Sebelah Selatan berbatasan dengan Desa Megati, Sebelah Barat berbatasan dengan Tukad Bunuhan. 
Di Desa Gunung Salak terdapat salah satu air terjun yaitu Air Terjun Tibu Sampi yang memiliki potensi untuk dikembangkan sebagai daya tarik wisata karena terdapat pesona air terjun yang tenang dan damai. Air terjun ini letaknya tersembunyi, tertutup pepohonan tetapi dengan pemandangan yang sangat alami dan suasana yang penuh dengan ketenangan. Akses untuk menuju air terjun ini bisa terbilang mudah, bisa dilewati motor ataupun mobil. Tetapi akses untuk mencapai air terjun ini masih cukup curam dan licin. Air terjun ini belum banyak dikenal oleh wisatawan sehingga tidak banyak wisatawan yang berkunjung. Penelitian ini penting dilakukan untuk mengetahui kendala-kendala apa yg menyebabkan terhambatnya pengembangan di Air Terjun Tibu Sampi sehingga dapat menentukan upaya-upaya pengembangan yang lebih lanjut dan pengembangan lebih optimal.

Melihat potensi yang dimiliki oleh Air Terjun Tibu Sampi maka air terjun ini memiliki peluang besar untuk dikembangkan sebagai daya tarik wisata. Namun potensi wisata ini belum dikembangkan dan dikelola secara optimal. Oleh karena itu penting dilakukan penelitian mengenai kendala dalam pengembangan dan upaya yang sebaiknya dilakukan dalam mengembangkan Air Terjun Tibu Sampi sebagai daya tarik wisata.

\section{KEPUSTAKAAN}

Sebagai acuan dalam penelitian ini, maka akan diuraikan jurnal terkait yang relevan yaitu jurnal yang ditulis oleh Sunarta (2012) yang berjudul "Dampak Perkembangan Pembangunan Sarana Akomodasi Wisata Terhadap Pariwisata Berkelanjutan di Bali". Jurnal ini menjelaskan mengenai dampak dari perkembangan pembangunan villa di Kuta Utara yang ditimbulkan baik secara positif maupun negatif yaitu pada aspek ekonomi, sosial budaya dan lingkungan. Secara ekonomi, dampak positif yang diperoleh adalah menigkatnya pendapatan asli daerah (PAD) dengan adanya pembayaran pajak yang diterima pemerintah daerah. Selain itu berkembangnya pembangunan sarana akomodasi juga membuka lapangan pekerjaan bagi masyarakat sekitarnya. Banyaknya pembangunan villa dan sarana akomodasi lainnya di lahan pertanian memberikan dampak negatif yang dirasakan oleh masyarakat terutama petani yang berada disekitar kawasan pembangunan villa. Dengan banyaknya pembangunan villa dan fasilitas pariwisata lainnya, banyak lahan produktif untuk lahan pertanian telah diubah menjadi tempattempat akomodasi pariwisata. Sehingga dari tahun ke tahun hasil produksi pertanian mengalami penurunan maka mengurangi pendapatan bagi petani.

Penelitian ini menggunakan konsep Daya Tarik Wisata, konsep pengembangan, dan konsep kendala guna menemukan apa saja kendala yang dihadapi dalam mengembangkan Air Terjun Tibu Sampi sebagai daya tarik wisata.

\section{METODE PENELITIAN}

Penelitian ini dilakukan di Air Terjun Tibu Sampi yang terletak di Banjar Kemetug Desa, Desa Gunung Salak, Selemadeg Timur, Tabanan.

Guna memberikan batasan dalam aspek data yang akan diteliti maka ditentukan ruang lingkup penelitian. Aspek data pertama pada penelitian ini yaitu kendala pengembangan Daya Tarik Wisata yang terdiri dari kendala internal dan kendala eksternal. Kemudian, aspek data kedua pada penelitian ini yaitu pengembangan Daya Tarik Wisata yang terdiri dari Pendidikan dan Pelatihan Pariwisata bagi Masyarakat Lokal, Peningkatan Produk Wisata, Penyebaran Informasi berupa Brosur dan Buku Panduan, Penataan dan Perbaikan Sarana Prasarana, Mengadakan Kerjasama dengan Pihak Investor, Menjadikan Kesenian Daerah sebagai Daya Tarik bagi Wisatawan, Dikembangkannya Paket-Paket Wisata.

Metode pengumpulan data yang digunakan dalam penelitian ini yaitu observasi langsung ke Air Terjun Tibu Sampi, kemudian melakukan wawancara terhadap Kepala Desa Gunung Salak. Penelitian ini menggunakan teknik penentuan sampel seleksi individu untuk dijadikan informan (Koentjaraningrat). 
Dimana informan pangkalnya adalah Kepala Desa Gunung Salak.

Pada teknik ini, informan pangkal merupakan orang yang memiliki pengetahuan meluas mengenai berbagai sektor dalam masyarakatnya, sehingga memiliki kemampuan untuk mengintroduksi peneliti kepada informaninforman lain yang kemudian disebut dengan informan kunci. Teknik analisis data yang digunakan adalah teknik analisis data deskriptif kualitatif.

\section{HASIL DAN PEMBAHASAN}

Air Terjun Tibu Sampi terletak di wilayah Banjar Kemetug Desa, Desa Gunung Salak. Air terjun ini sebeenarnya sudah ada sejak lama. Keberadaan air terjun ini baru diketahui secara luas sejak januari 2016, dikarenakan beberapa pengunjung menyebarkan foto-fotonya melalui media sosial. Air Terjun Tibu Sampi muncul dari tebing setinggi 10 meter. Akses jalan menuju Air Terjun Tibu Sampi bisa bisa dilalui menggunakan kendaraan roda dua dan roda empat. Oleh masyarakat sekitar, Air Terjun Tibu Sampi disebut jadi primadona, karena pengunjung bisa langsung berenang menikmati sensasi bening dan segarnya air terjun

Air Terjun Tibu Sampi memiliki panorama alam yang sangat indah dengan lingkungan yang alami. Keunikan dari Air Terjun Tibu Sampi ini adalah airnya yang terasa agak manis. Menurut keyakinan masyarakat setempat, rasa manis pada Air Terjun Tibu Sampi terjadi karena airnya dialiri dari 10 sumber mata air alami.

Air Terjun Tibu Sampi yang menjadi daya tarik wisata tidak lepas dari kendalakendala yang dapat menghambat laju pengembangannya, begitu pula dengan pengembangan potensi yang ada dilapangan apabila terdapat kendalakendala atau hambatan-hambatan, maka perlu diambil kebijakan yang baik diantara komponen-komponen pariwisata yang ada. Berikut ini adalah kendala-kendala dalam pengembangan daya tarik wisata Air Terjun Tibu Sampi :

Dalam pengembangan Air Terjun Tibu Sampi terdapat kendala internal yang berasal dari dalam, yaitu kendala yang berasal dari pihak pengelola itu sendiri, air terjun ini dikelola oleh Desa Gunung Salak, adapun kendala-kendala tersebut antara lain :

Pertama, kendala pada modal, dalam pengembangan Air Terjun Tibu Sampi, kendala utamanya terletak pada minimnya modal yang dimiliki oleh Desa Gunung Salak sehingga terhambatnya pengembangan daya tarik wisata Air Terjun Tibu Sampi. Hal ini dapat dilihat dari belum adanya penambahan-penambahan fasilitas-fasilitas pendukung disekitar daya tarik wisata Air Terjun Tibu Sampi ini. Terlihat masih kurangnya fasilitas pendukung seperti tangga dan pagar pengaman, toilet dan tempat parkir di daya tarik wisata ini. Hal ini akan mempengaruhi kunjungan wisatawan yang datang ke Air Terjun Tibu Sampi. Keterbatasan modal juga disebabkan karena belum adanya campur tangan dari pemerintah. Hanya Desa Gunung Salak yang mengelola Air Terjun Tibu Sampi ini, sehingga pengembangan belum bisa dijalankan secara optimal.

Kedua, Sumber Daya Manusia di Bidang Pariwisata, masyarakat Desa Gunung Salak masih banyak yang belum mengerti pariwisata, terlihat dari kurangnya sumber daya manusia yang memadai di bidang pariwisata, mengakibatkan lambatnya perkembangan kegiatan kepariwisataan. Berdasarkan informasi yang diperoleh dari Kantor Desa Gunung Salak, tingkat pendidikan masyarakat kurang memadai. Data mengenai tingkat pendidikan masyarakat Desa Gunung Salak dapat dilihat pada tabel 4.1 
Tabel 4.1

Data Tingkat Pendidikan Masyarakat Desa Gunung Salak

\begin{tabular}{|c|c|}
\hline Tingkat Pendidikan & Jumlah \\
\hline Tidak Sekolah & 0 orang \\
\hline SD & 644 orang \\
\hline SMP & 227 orang \\
\hline SMA & 427 orang \\
\hline Diploma & 46 orang \\
\hline Perguruan Tinggi & 45 orang \\
\hline Jumlah Total & $\mathbf{1 . 3 8 9}$ \\
\hline
\end{tabular}

Sumber : Data Kantor Desa Gunung Salak

Hanya sedikit dari masyarakat Desa Gunung Salak yang memiliki pendidikan dengan latar belakang tinggi. Hal ini terlihat dari keinginan sumber daya manusia untuk melanjutkan ke jenjang pendidikan yang lebih tinggi masih kurang banyak. Untuk itu perlu diambil langkah-langkah yang tepat untuk dapat meningkatkan kualitas sumber daya manusia.

Ketiga, Belum maksimalnya promosi yang dilakukan membuat daya tarik wisata Air Terjun Tibu Sampi ini belum banyak dikenal wisatawan. Karena belum dikelola secara optimal dan juga kurangnya anggaran untuk mengelola Air Terjun Tibu Sampi ini maka promosi tidak bisa dilakukan dengan intensif. Namun villa-villa disekitar air terjun ini mulai mempromosikannya untuk wisatawan yang mengunjungi villa mereka kemudian diajak untuk mengunjungi Air Terjun Tibu Sampi. Mulanya air terjun ini diketahui oleh wisatawan melalui media sosial seperti Instagram dan Facebook, kemudian wisatawan mulai berdatangan dari berbagai daerah. Biasanya wisatawan-wisatawan yang datang pada saat akhir pekan atau pada saat musim liburan. Wisatawan lainnya mulanya mengetahui adanya air terjun ini karena merupakan jalur yang dilalui saat offroad. Sehingga menjadi tempat persinggahannya sebelum melanjutkan kegiatan offroadnya. Ada juga wisatawan yang mengetahui keberadaan air terjun ini dari sanak keluarga dan teman. Selama ini promosi baru dilakukan secara mulut ke mulut dan dimedia massa seperti televisi yaitu Net TV.

Pengembangan Air Terjun Tibu Sampi juga memiliki kendala eksternal yaitu kendala yang berasal dari luar. Kedala eksternalnya adalah kurangnya peran pihak swasta. Peran pihak swasta sangatlah penting terhadap proses pengembangan Air Terjun Tibu Sampi menjadi daya tarik wisata, namun selama ini belum ada pihak swasta yang berkontribusi. Seperti yang sudah dibahas sebelumnya, pihak swasta atau villa yang ada disekitar Air Terjun Tibu Sampi hanya mempromosikan air terjun ini untuk wisatawan yang berkunjung ke villa mereka.

Peran pihak swasta dalam hal ini sangat diperlukan dengan pertimbangan bahwa mereka memiliki dana untuk membangun sarana pariwisata. Beberapa villa yang ada di sekitar Air Terjun Tibu Sampi ini, seperti Bali Eco Stay Villa dan Clove Tree Hill Boutique Bali Villas. Clove Tree Hill Boutique Bali Villas ini juga membuat tangga ke bawah untuk menuju Air Terjun Tibu Sampi, tetapi hanya untuk wisatawan yang berkunjung ke villa mereka.

Berdasarkan permasalahan yang dihadapi dalam pengembangan Air Terjun Tibu Sampi sebagai daya tarik wisata, upaya pengembangan yang dilakukan merupakan tindak lanjut dari strategi-strategi atau rencana-rencana untuk lebih mengenalkan daya tarik wisata yang dianggap layak untuk dikembangkan sebagai salah satu tujuan wisata. Beberapa upaya yang dilakukan dalam pengembangan Air Terjun Tibu Sampi di Kabupaten Tabanan adalah :

Upaya yang pertama, yaitu : Pendidikan dan Pelatihan Pariwisata bagi Masyarakat Lokal. Sumber daya manusia yang berkualitas merupakan salah satu persyaratan yang harus dipenuhi. Menurut Kepala Desa Gunung Salak, program pendidikan dan pelatihan pariwisata ini memang akan dilaksanakan oleh Pemerintah Provinsi dengan pihak ketiga yang dimotori oleh Swastika Bali. Adapun cara-cara untuk melakukan pelatihan bagi masyarakat Desa Gunung Salak adalah mengadakan penyuluhan-penyuluhan pariwisata yang dilakukan oleh Dinas Pariwisata setempat, kursus bahasa asing dan mengadakan seminar yang bertemakan 
lingkungan hidup dan cara pengelolaan daya tarik wisata Air Terjun Tibu Sampi.

Selain itu pengelola perlu mengadakan pembinaan terhadap generasi muda untuk meningkatkan pengetahuan dan pengalaman mengenai kepariwisataan. Generasi mudalah yang berperan penting nantinya untuk memajukan pengembangan Air Terjun Tibu Sampi ini. Sedangkan untuk masyarakat lokal perlu dibentuk kelompok sadar wisata untuk menambah pemahaman tentang pentingnya pariwisata dan pelestarian alam di Desa Gunung Salak.

Upaya yang kedua yaitu : Peningkatan Produk Wisata, pengembangan Air Terjun Tibu Sampi hanya mengandalkan keindahan dan panorama alamnya. Jadi wisatawan hanya dapat menikmati panorama air terjun dan sawah yang berundak-undak, sehingga menimbulkan kesan yang monoton. Oleh karena itu perlu adanya inovasi baru untuk produk-produk wisata lain yang dapat ditawarkan kepada wisatawan seperti kesenian daerah, tari-tarian tradisional.

Daya tarik wisata kesenian ini perlu dikembangkan secara maksimal supaya ada nilai tambah lagi untuk pengembangan Air Terjun Tibu Sampi ini. Kesenian Okokan bisa dijadikan sebagai produk wisata karena berbeda dengan kesenian-kesenian daerah lainnya.

Upaya yang ketiga merupakan Penyebaran Informasi berupa Brosur dan Buku Panduan. Penyebaran brosur dan buku panduan merupakan hal yang penting dalam meningkatkan dan mengenalkan Air Terjun Tibu Sampi ke dunia pariwisata, baik itu kepada wisatawan nusantara maupun wisatawan mancanegara. Brosur dan buku panduan ini untuk menginformasikan tentang daya tarik wisata Air Terjun Tibu Sampi dalam bentuk foto atau gambar yang menarik perhatian bagi yang melihatnya, termasuk sarana yang ada di daya tarik ini secara singkat dan jelas.

Didalam brosur dan buku panduan ini selain berisi tentang potensi alam yang dimiliki Air Terjun Tibu Sampi, harus juga berisi tentang potensi kesenian okokan yang khas dari Desa Gunung Salak. Sehingga wisatawan tahu apa saja potensi yang dimiliki dan ingin mengunjungi Air Terjun Tibu Sampi ini.
Upaya keempat, Penataan dan Perbaikan Sarana Prasarana. Akses untuk menuju Air Terjun Tibu Sampi masih harus diperbaiki, menurut Kepala Desa Gunung Salak perbaikan jalan akan dilaksanakan dan memang sudah dianggarkan. Selain itu, harus disediakannya fasilitas pendukung seperti toilet, tempat parkir, pembuatan tangga dan pagar pengaman untuk turun ke air terjun, dan sarana prasarana lainnya. Sarana dan prasarana sangat penting untuk menunjang kelangsungan pengembangan Air Terjun Tibu Sampi dan juga mempengaruhi tingkat kunjungan wisatawannya.

Upaya kelima, Mengadakan Kerjasama dengan Pihak Investor. Peran serta pihak swasta sangat membantu terhadap pengembangan Air Terjun Tibu Sampi sebagai daya tarik wisata. Selama ini peran serta dari pihak swasta belum ada hanya saja pihak swasta dari villa yang ada di sekitar Air Terjun Tibu Sampi mempromosikan air terjun ini tetapi hanya untuk wisatawan yang berkunjung ke villa mereka. Selain mempromosikan air terjun ini, ada villa yang membuat tangga untuk menuju air terjun ini, tetapi hanya saja diperbolehkan untuk wisatawan yang menginap atau berkunjung ke villa mereka.

Air Terjun Tibu Sampi ini hanya dikelola oleh desa. Peran serta dari pihak swasta sangat diperlukan dengan adanya pertimbangan bahwa pihak swasta mempunyai dana yang cukup. Peran pihak swasta juga diharapkan untuk lebih banyak mempromosikan Air Terjun Tibu Sampi dan membuat paket wisata untuk mengunjungi Air Terjun Tibu Sampi.

Upaya yang keenam, Menjadikan Kesenian Daerah sebagai Daya Tarik bagi Wisatawan. Untuk memberikan manfaat ekonomis yang nyata kepada masyarakat dilakukan dengan mengikutsertakan kesenian yang dimiliki oleh masyarakat Desa Gunung Salak sebagai salah satu daya tarik wisata, untuk itu perlu dilakukan promosi kesenian. Karena belum adanya promosi yang menjelaskan tentang produk kesenian masyarakat lokal. Promosi kesenian daerah sangat diperlukan untuk menunjang keberlanjutan pengembangan pariwisata. Terutama mempromosikan 
kesenian okokan yang menjadi ciri khas Desa Gunung Salak.

\section{SIMPULAN DAN SARAN}

Berdasarkan hasil dan pembahasan, kendala-kendala yang dihadapi dalam pengembangan Air Terjun Tibu Sampi adalah kendala internal dan eksternal. Dari penelitian yang telah dilakukan ditemukan tiga kendala internal yaitu yang pertama keterbatasan modal yang dimiliki oleh Desa Gunung Salak sebagai pengelola, kedua kurang tersedianya sumber daya manusia yang memadai dibidang pariwisata dan yang ketiga masih kurang maksimalnya promosi yang dilakukan dalam pengembangan daya tarik wisata. Sedangkan kendala eksternal ditemukan adalah belum adanya kontribusi dari pihak swasta.

Dari berbagai kendala yang selama ini menghambat pengembangan Air Terjun Tibu Sampi sebagai daya tarik di Kabupaten Tabanan, masyarakat hendaknya melakukan beberapa upaya sebagai berikut : Pendidikan dan Pelatihan Pariwisata bagi Masyarakat Lokal, Peningkatan Produk Wisata, Penyebaran Informasi berupa Brosur dan Buku Panduan, Penataan dan Perbaikan Sarana Prasarana, Mengadakan Kerjasama dengan Pihak Investor, Menjadikan Kesenian Daerah sebagai Daya Tarik bagi Wisatawan dan Dikembangkannya Paket-Paket Wisata.

Adapun saran yang dapat diberikan untuk kemajuan pengembangan Air Terjun Tibu Sampi, yaitu: Untuk mencapai pengembangan potensi yang optimal diperlukan kerjasama yang baik dari berbagai pihak, khususnya pemerintah daerah Kabupaten Tabanan, perlu adanya peningkatan fasilitas seperti jalan, sarana transportasi, sarana telekomunikasi dan informasi, perlu dibentuknya kelompok sadar wisata, serta perlu dilakukan promosi yang lebih sering dilakukan dan bekerjasama dengan biro perjalanan wisata, pemerintah, masyarakat dan lembaga kepariwisataan lainnya.

\section{DAFTAR PUSTAKA}

Anonim. 2009. Undang-Undang RI No 10 Tahun 2009 tentang Kepariwisataan.

Sunarta, I Nyoman; dkk. 2012. Dampak Perkembangan Pembangunan Sarana Akomodasi Wisata terhadap Pariwisata Berkelanjutan di Bali. Jurnal Ilmiah Pariwisata, [S.I.]. ISSN 1858-070x.

Swarbroke J. 1998. Sustainable Tourism Management. British Library, London UK: CABI Publishing.

Marpaung, H. 2002. Pengetahuan Kepariwisataan. Ed Revisi. Alfabeta. Bandung.

Paturusi, Samsul. 2001. Perencanaan Tata Ruang Kawasan Pariwisata (Kajian Pariwisata Program Pascasarjana). Denpasar: Universitas Udayana. 